\title{
Non-contiguous finished genome sequence and description of Bacillus algeriensis sp. nov.
}

\author{
Esma Bendjama ${ }^{1,2,3}$, Lotfi Loucif ${ }^{1,2,3}$, Seydina M. Diene ${ }^{1}$, Caroline Michelle ${ }^{1}$, Djamila Gacemi- \\ Kirane $^{2}$, Jean-Marc Rolain ${ }^{1 *}$ \\ ${ }^{1}$ Unité de recherche sur les maladies infectieuses et tropicales émergentes (URMITE), UMR \\ CNRS, IHU Méditerranée Infection, Faculté de Médecine et de Pharmacie, Aix-Marseille- \\ Université, Marseille, France. \\ ${ }^{2}$ Département de Biochimie, Faculté des Sciences, Université Badji Mokhtar, Annaba, Algé- \\ rie \\ ${ }^{3}$ Département des Sciences Biologiques, Faculté des Sciences, Université El Hadj Lakhdar, \\ Batna, Algérie. \\ *Correspondence: Jean-Marc Rolain (jean-marc.rolain@univ-amu.fr)
}

Keywords: Bacillus algeriensis, hypersaline environments, sediments, genome, taxonogenomics
Strain $\mathrm{EB} 01^{\top}$ sp. nov. is the type strain of Bacillus algeriensis, a new species within the genus Bacillus. This strain, whose genome is described here, was isolated from sediment sample of the hypersaline lake Ezzemoul sabkha in northeastern Algeria. B. algeriensis is a facultative anaerobic Gram-positive bacillus. Here we describe the features of this organism, together with the complete genome sequence and annotation. The 5,269,577 bp long genome con- tains 5,098 protein-coding and 95 RNA genes, including 12 rRNA genes.

\section{Introduction}

Bacillus algeriensis sp. nov. strain EB01 ${ }^{\mathrm{T}}$ (= CSUR P857 = DSM 27334) is the type strain of $B$. algeriensis sp. nov. It is a new Gram-positive, facultatively anaerobic, motile, indole-negative, rod shaped bacterium with rounded ends. It was isolated from a sediment sample from the hypersaline lake Ezzemoul sabkha in the Oum-ElBouaghi region in northeastern Algeria, which is an important wintering and resting site for several species of waterbirds, including the Greater Flamingo. This site is one of the Ramsar convention wetlands (http://www.ramsar.org). The genus Bacillus was created by Cohn about 142 years ago [1], and mainly comprises Gram-positive, rodshaped, aerobic or facultatively anaerobic, sporeforming bacteria. The genus includes 279 species and 7 subspecies with validly published names [2]. Members of Bacillus genus are ubiquitous in nature, ranging from freshwater to marine sediments and from hot springs and desert sands to Arctic soils; many strains have been isolated from the gastrointestinal tracts of various insects and animals, from vegetation and from food [3]. Bacillus strains are biotechnologically priceless be- cause of their high capacity to produce a wide range of antimicrobial compounds, enzymes and other metabolites that can be used in industry [4,5]. Some species of Bacillus are pathogenic, such as B. anthracis (responsible for causing anthrax) [6] and B. cereus (a major cause of food poisoning) [7]. Others are opportunists in immunocompromised patients, and may also be involved in various human infections, including pneumonia, endocarditis, ocular, cutaneous, bone or central nervous system infections and bacteremia [8].The current bacterial taxonomy is based on a combination of various phenotypic and genetic criteria $[9,10]$. However, the three essential genetic criteria that are used, comprising $16 \mathrm{~S}$ rRNA gene based phylogeny [11], $\mathrm{G}+\mathrm{C}$ content, and DNA-DNA hybridization [10,12] exhibit several drawbacks. As a result of the recent decrease in the cost of genomic sequencing, it has been proposed that whole genome sequencing information and MALDI-TOF spectrum [13] be combined with the main phenotypic characteristics as a polyphasic approach strategy (taxono-genomics) to describe new bacterial taxa [14-26]. 
Here we present a summary classification and a set of features for $B$. algeriensis sp. nov. strain EB01 ${ }^{\mathrm{T}}$ together with the description of the complete genome sequence and annotation. These characteristics support the circumscription of the species B. algeriensis.

\section{Classification and features}

In July 2012, a sediment sample was aseptically collected in sterile bottles, $15 \mathrm{~cm}$ below the evaporite crust of the hypersaline lake Ezzemoul sabkha of Oum-El-Bouaghi region in northeastern Algeria. Samples were transferred in a cooler $\left(4^{\circ} \mathrm{C}\right)$ to our lab in Algeria. Samples were processed the same day. Sediments were diluted 1:10 $\mathrm{v} / \mathrm{v}$ with sterile saline water $(0.9 \% \mathrm{NaCl})$ and vigorously shaken, tenfold serial dilutions $\left(10^{-1}-10^{-5}\right)$ of the sediment suspension were plated in Nutrient Agar (NA) medium (meat extract $1 \mathrm{~g} / \mathrm{l}$, peptone $5 \mathrm{~g} / \mathrm{l}$, yeast extract $2 \mathrm{~g} / \mathrm{l}$, sodium chloride 5 $\mathrm{g} / \mathrm{l}$, agar $15 \mathrm{~g} / \mathrm{l}$ ) and the plates were incubated at $30^{\circ} \mathrm{C}$ for $24-72 \mathrm{~h}$. In order to obtain a pure culture, colonies were transferred to fresh NA medium. Bacillus algeriensis sp. nov. strain EB01 ${ }^{\mathrm{T}}$ (Table 1) was isolated in July 2012 by cultivation under aerobic conditions at $30^{\circ} \mathrm{C}$. This strain exhibited a 97.0\% 16S rRNA nucleotide sequence similarity with Bacillus subterraneus type strain DSM13966 (Figure 1), the phylogenetically closest validly published Bacillus species. These values were lower than the $98.7 \% 16 \mathrm{~S}$ rRNA gene sequence threshold recommended by Stackebrandt and Ebers to delineate a new species without carrying DNA DNA hybridizidation [11].

Table 1. Classification and general features of Bacillus algeriensis strain $\mathrm{EB} 01^{\top}$

\begin{tabular}{|c|c|c|c|}
\hline MIGS ID & Property & Term & Evidence code $^{\mathrm{a}}$ \\
\hline & \multirow{8}{*}{ Current classification } & Domain Bacteria & TAS [27] \\
\hline & & Phylum Firmicutes & TAS [28-30] \\
\hline & & Class Bacilli & TAS [31,32] \\
\hline & & Order Bacillales & TAS $[33,34]$ \\
\hline & & Family Bacillaceae & TAS $[33,35]$ \\
\hline & & Genus Bacillus & TAS $[1,33,36]$ \\
\hline & & Species Bacillus algeriensis & IDA \\
\hline & & Type strain $\mathrm{EBO} 1^{\top}$ & IDA \\
\hline & Gram stain & Positive & IDA \\
\hline & Cell shape & Rod-shaped & IDA \\
\hline & Motility & Motile & IDA \\
\hline & Sporulation & Sporulating & IDA \\
\hline & Temperature range & Between $37^{\circ} \mathrm{C}$ and $55^{\circ} \mathrm{C}$ & IDA \\
\hline & Optimum temperature & $37^{\circ} \mathrm{C}$ & IDA \\
\hline & & Growth in LB medium $+0-2.5 \%$ & \\
\hline MIGS-6.3 & Salinity & $\mathrm{NaCl}$ & IDA \\
\hline \multirow[t]{3}{*}{ MIGS-22 } & Oxygen requirement & Facultative anaerobic & IDA \\
\hline & Carbon source & Unknown & NAS \\
\hline & Energy source & Unknown & NAS \\
\hline MIGS-6 & Habitat & Hypersaline sediment sample & IDA \\
\hline \multirow[t]{3}{*}{ MIGS-15 } & Biotic relationship & Free living & IDA \\
\hline & Pathogenicity & Unknown & NAS \\
\hline & Biosafety level & 2 & NAS \\
\hline MIGS-14 & Isolation & Sediment of Ezzemoul Sabkha Lake & IDA \\
\hline MIGS-4 & Geographic location & Algeria & IDA \\
\hline & Sample collection & July 2012 & \\
\hline MIGS-5 & time & & IDA \\
\hline MIGS-4.1 & Latitude & 35.88167 & IDA \\
\hline MIGS-4.1 & Longitude & 6.503272 & IDA \\
\hline MIGS-4.3 & Depth & Unknown & NAS \\
\hline MIGS-4.4 & Altitude & $800 \mathrm{~m}$ & IDA \\
\hline
\end{tabular}

aEvidence codes - IDA: Inferred from Direct Assay, TAS: Traceable Author Statement (i.e., a direct report exists in the literature), NAS: Non traceable Author Statement (i.e., not directly observed for the living, isolated sample, but based on a generally accepted property for the species, or anecdotal evidence). These evidence codes are from the Gene Ontology project [37]. If the evidence is IDA, then the property was directly observed for a live isolate by one of the authors or an expert mentioned in the acknowledgements. 


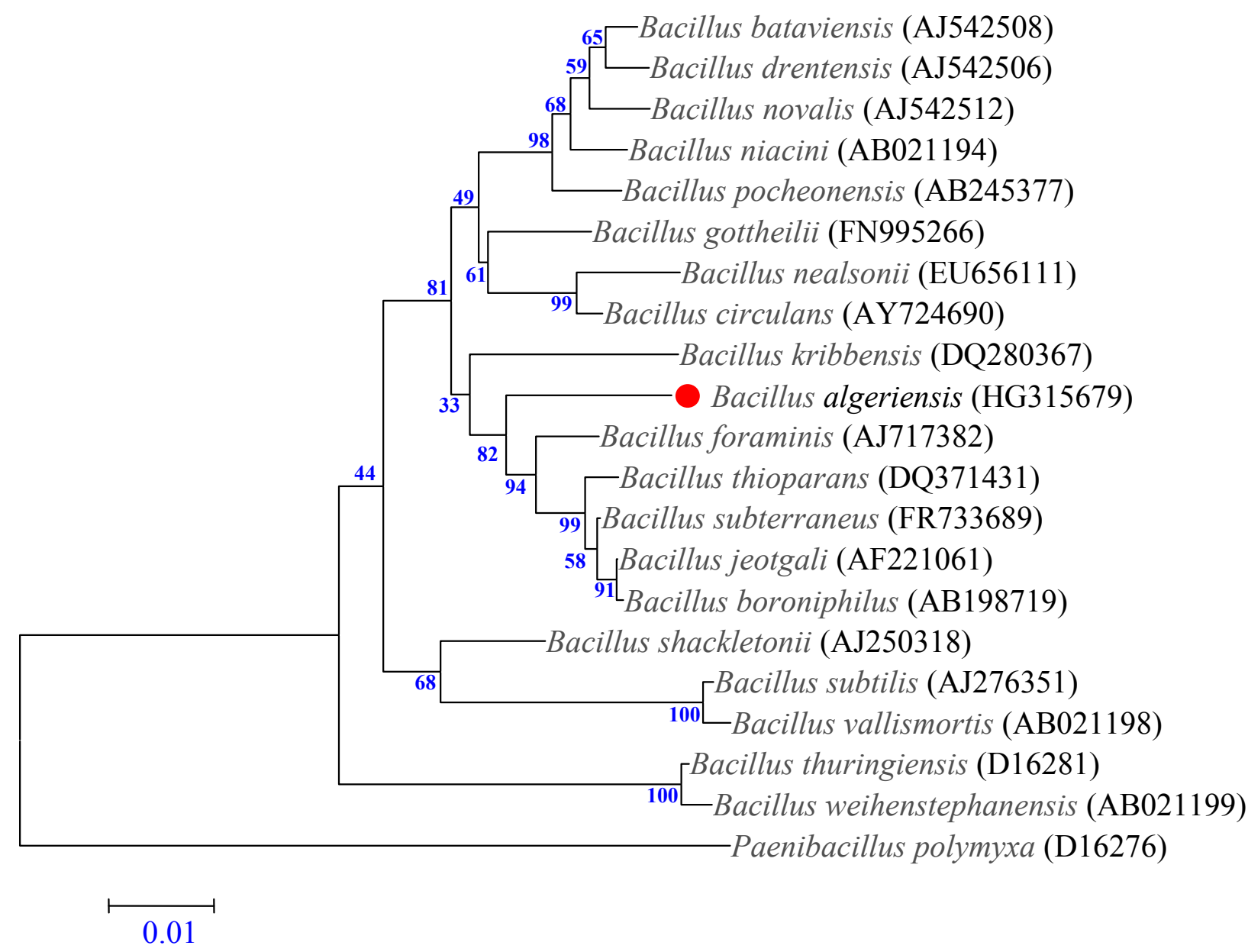

Figure 1. A consensus phylogenetic tree based on $16 \mathrm{~S}$ rRNA gene sequence comparisons, highlighting the position of strain $\mathrm{EB} 01^{\top}$ Bacillus algeriensis relative to other type strains within the Bacillus genus. GenBank accession numbers are displayed in parentheses. Sequences were aligned using CLUSTALW, and phylogenetic inferences made using the neighbor-joining method [38] within the MEGA 5 software [39]. Numbers above the nodes are percentages of bootstrap values from 1,000 replicates that support the node. Paenibacillus polymyxa was used as the outgroup. The scale bar represents 0.01 substitutions per nucleotide position.

Six different growth temperatures $(25,30,37,45$, 50 and $\left.55^{\circ} \mathrm{C}\right)$, nine $\mathrm{NaCl}$ concentrations $(0,2.5,5$, $7.5,10,15,20,25,30 \%)$ and ten pHs $(5,6,6.5,7$, $7.5,8,8.5,9,10,11)$ were tested. Growth occurred at all tested temperatures, however the optimal growth was observed at $37^{\circ} \mathrm{C}$, between $0 \%$ and $2.5 \% \mathrm{NaCl}$ concentration and $\mathrm{pH}$ in the range of 6.5-9 (optimum at pH 7). Colony morphology was observed on sheep blood agar (BioMerieux) after $24 \mathrm{~h}$ of aerobic incubation under optimal growth conditions, the colonies of strain EB01 ${ }^{\mathrm{T}}$ were circular, light yellow, smooth and $2 \mathrm{~mm}$ in diameter. Growth of the strain was tested in anaerobic and microaerophilic atmospheres using GasPak EZ Anaerobe Pouch (Becton, Dickinson and Compa- ny) and CampyGen Compact (Oxoid) systems, respectively, and in aerobic atmosphere, with or without $5 \% \mathrm{CO}_{2}$. Growth was achieved under aerobic (with and without CO2) and microaerophilic conditions but weak growth was observed under anaerobic conditions. Gram staining showed Gram-positive rods (Figure 2). Cells grown on agar sporulate. A motility test was positive. The size of cells were determined by negative staining transmission electron microscopy on a Technai $\mathrm{G}^{2}$ Cryo (FEI) at an operating voltage of $200 \mathrm{kV}$, the rods have a length ranging from $2.4 \mu \mathrm{m}$ to $4.9 \mu \mathrm{m}$ (mean $3.6 \mu \mathrm{m}$ ) and a diameter ranging from 0.7 $\mu \mathrm{m}$ to $1.1 \mu \mathrm{m}$ (mean $0.8 \mu \mathrm{m}$ ) (Figure 3 ). 


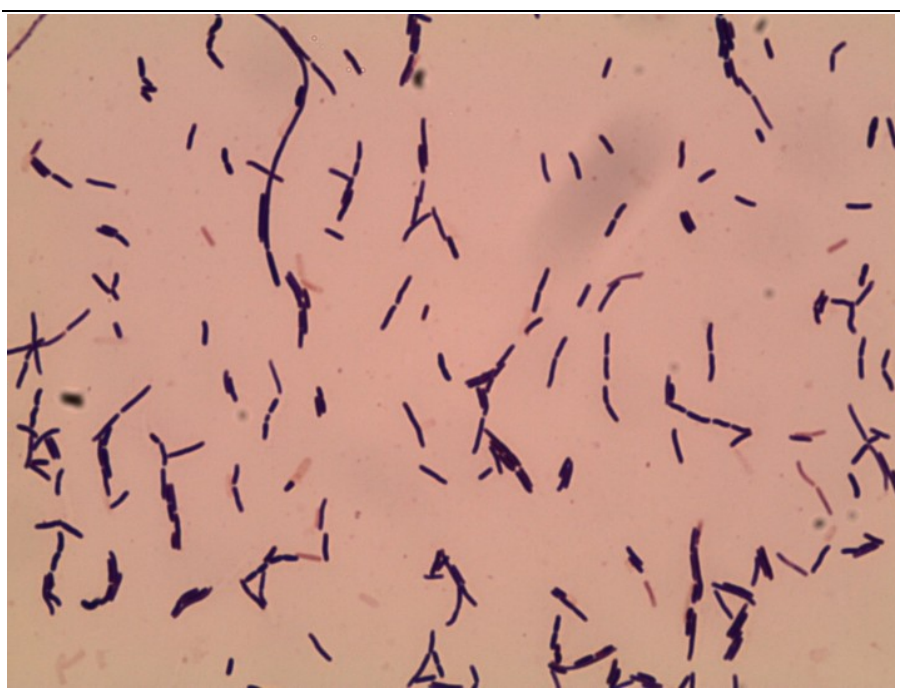

Figure 2. Gram stain of $B$. algeriensis strain $\mathrm{EB}^{2} 1^{\top}$.

Strain EB01 ${ }^{\mathrm{T}}$ exhibited catalase activity but oxidase activity was negative. Using the commercially available API 50CH system (BioMerieux) according to the manufacturer's instructions, a weak positive reaction was observed for D-ribose, Dglucose, D-fructose, methyl $\alpha$-D-glucopyranoside, $\mathrm{N}$-acetylglucosamine, D-maltose, D-lactose, Dmelibiose, D-saccharose, D-trehalose, D-tagatose, and hydrolysis of starch. Other tests were negative. Using the API ZYM system (BioMerieux), positive reactions were observed for alkaline phosphatase, esterase (C4), esterase lipase (C8), leucine arylamidase, $\alpha$-chymotrypsin, $\beta$-glucuronidase, $\alpha$-glucosidase, $\mathrm{N}$-acetyl-glucosaminidase and a weak positive reaction was observed for acid phosphatase. The nitrate reduction and $\beta$ galactosidase reaction was also positive, but urease and indole production were negative. B. algeriensis was susceptible to amoxicillin, nitrourantoin, erythromycin, doxycycline, rifampicin, vancomycin, gentamicin, imipenem, trimethoprim-sulfamethoxazole, ciprofloxacin, ceftriaxone and amoxicillin-clavulanic acid, but resistant to nalidixic acid.

When compared to other Bacillus species [40-48], Bacillus algeriensis sp. nov. strain EB01 ${ }^{\mathrm{T}}$ exhibited the phenotypic differences detailed in (Table 2).

Matrix-assisted laser-desorption/ionization timeof-flight (MALDI-TOF) MS protein analysis was performed as previously described $[26,49,50]$. Briefly, strain $\mathrm{EB}^{\mathrm{T}} 1^{\mathrm{T}}$ was plated on $5 \%$ sheep blood-enriched Columbia agar (BioMerieux) and incubated for $24 \mathrm{~h}$ at $37^{\circ} \mathrm{C}$. Isolated bacterial colo-
Figure 3. Transmission electron micrograph of $B$. algeriensis strain $\mathrm{EB}^{\top} 1^{\top}$ made using a Technai $\mathrm{G}^{2}$ Cryo (FEl) at an operating voltage of $200 \mathrm{kV}$. The scale bar represents $500 \mathrm{~nm}$.

nies were picked, and then deposited as a thin film in 12 replicates on a MALDI-TOF steel target plate (Bruker Daltonics, Bremen, Germany). The plates were allowed to dry at room temperature. Each deposit was overlaid with $1.5 \mu \mathrm{l}$ of matrix solution containing $\alpha$-cyano-hydroxycinnamic acid (Sigma, Saint-Quentin Fallavier, France) saturated with $50 \%$ acetonitrile, $2.5 \%$ trifluoroacetic acid and high-performance liquid chromatography (HPLC)grade water, and allowed to co-crystallize with the sample. Measurements were conducted using the Microflex LT spectrometer (Bruker Daltonics). Spectra were recorded in the linear positive ion mode over a mass range of 2 to $20 \mathrm{kDa}$. The acceleration voltage was $20 \mathrm{kV}$. Spectra were collected as a sum of 240 shots across a spot. The 12 EB01 ${ }^{\mathrm{T}}$ spectra were imported into the MALDI BioTyper software (version 3.0, Bruker) and analyzed by standard pattern matching (with default parameter settings) against 6,335 bacterial spectra including 210 spectra from 104 Bacillus species, used as reference data, in the BioTyper database. A score enabled the identification, or not, from the tested species: a score $>2$ with a validated species enabled the identification at the species level, a score $>1.7$ but $<2$ enabled the identification at the genus level; and a score $<1.7$ did not enable any identification. For strain EB01' , the scores obtained ranged from 1.15 to 1.60 thus suggesting that our isolate was a new species. We added the spectrum from strain EB01 ${ }^{\mathrm{T}}$ (Figure 4) to our database. Spectrum differences with other of Bacillus species are shown in (Figure 5). 


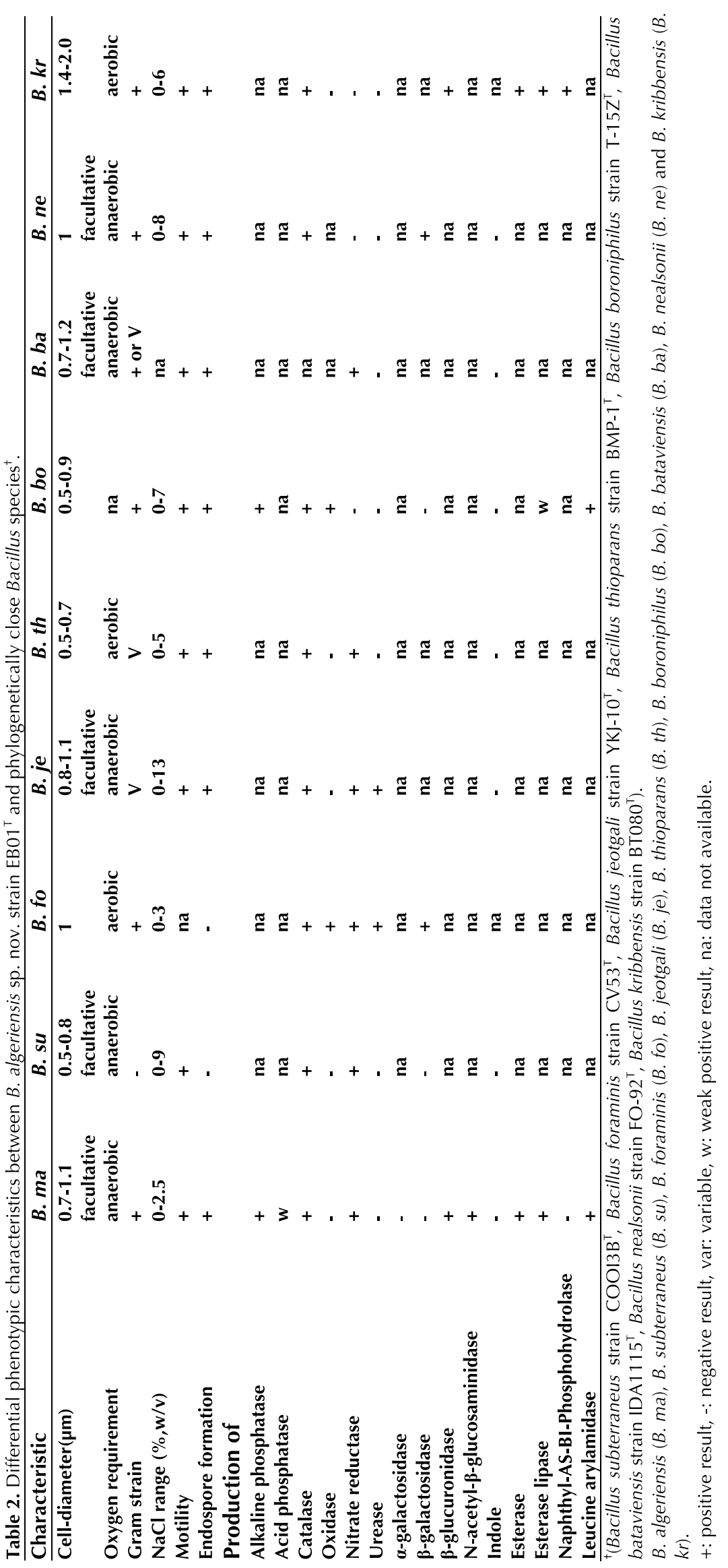




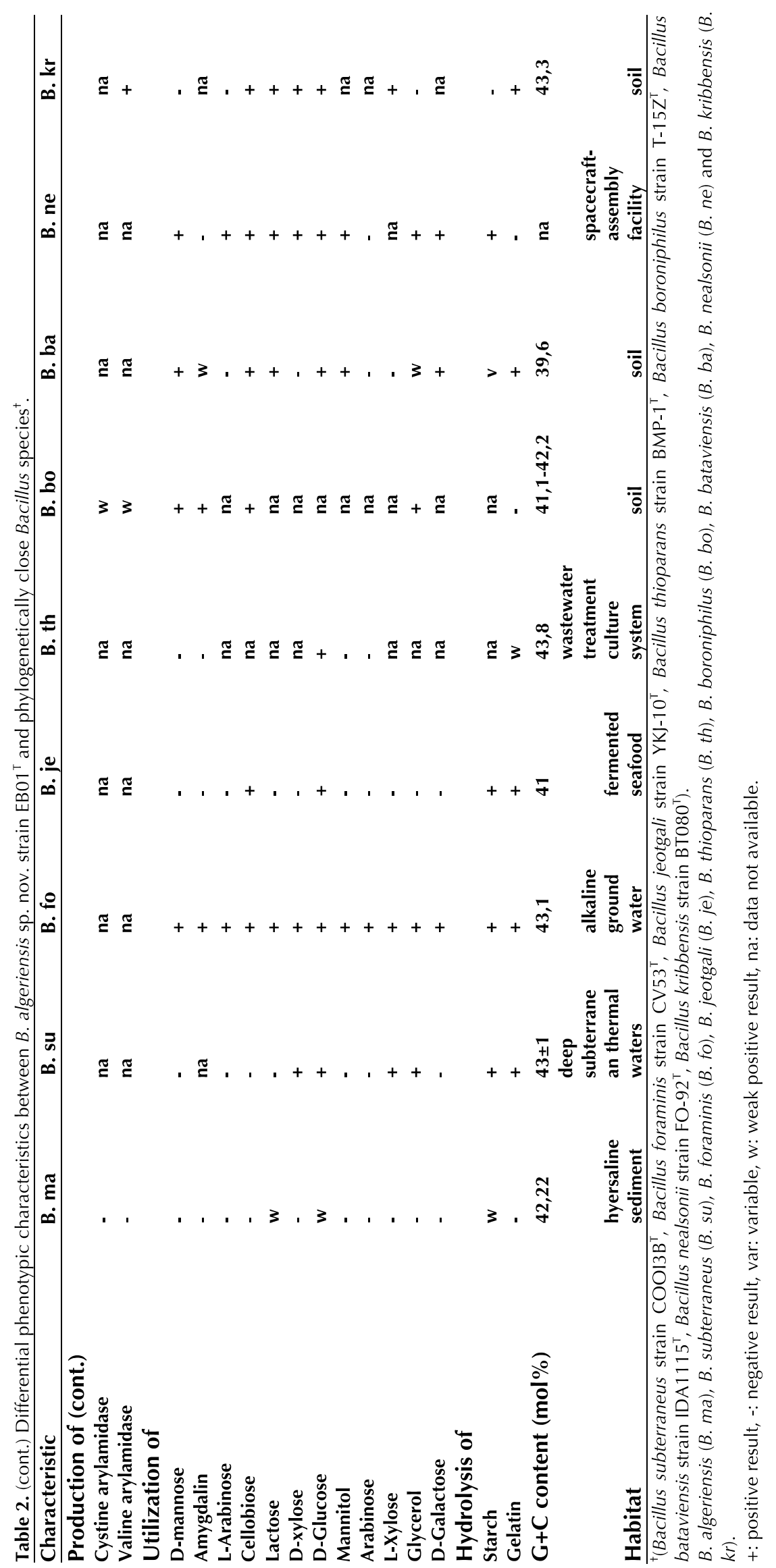




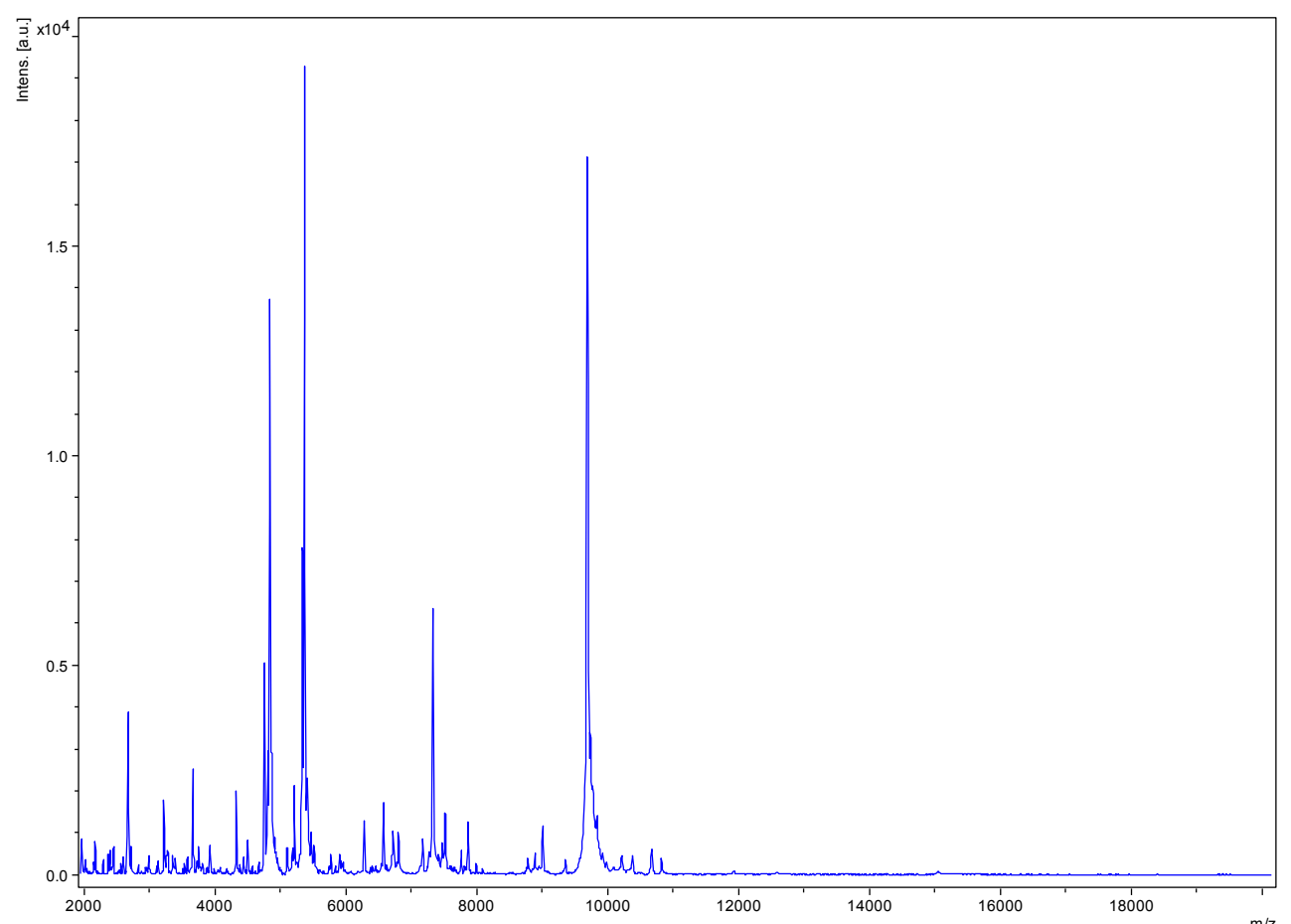

Figure 4. Reference mass spectrum from $B$. algeriensis strain EB01 ${ }^{\top}$. Spectra from 12 individual colonies were compared and a reference spectrum was generated.

B. weihenstephanensis DSM $11821^{\mathrm{T}}$

B. vallismortis DSM $11031^{\mathrm{T}}$

B. thuringiensis DSM $2046^{\mathrm{T}}$

B. thioparans CIP $109765^{\mathrm{T}}$

B. subtilis subsp. subtilis DSM $10^{\mathrm{T}}$

B. subterraneus DSM $13966^{\mathrm{T}}$

B. shackletonii DSM $18868^{\mathrm{T}}$

B. novalis DSM $15603^{\mathrm{T}}$

B. niacini DSM $2923^{\mathrm{T}}$

B. nealsonii DSM $15077^{\mathrm{T}}$

B. massilioalgeriensis $\mathrm{EB} \mathrm{1}^{\mathrm{T}}$

B. jeotgali DSM $18226^{\mathrm{T}}$

B. flexus DSM $1320^{\mathrm{T}}$

B. circulans DSM $11^{\mathrm{T}}$

B. bataviensis DSM $15601^{\mathrm{T}}$

B. asahii CIP $108638^{\mathrm{T}}$

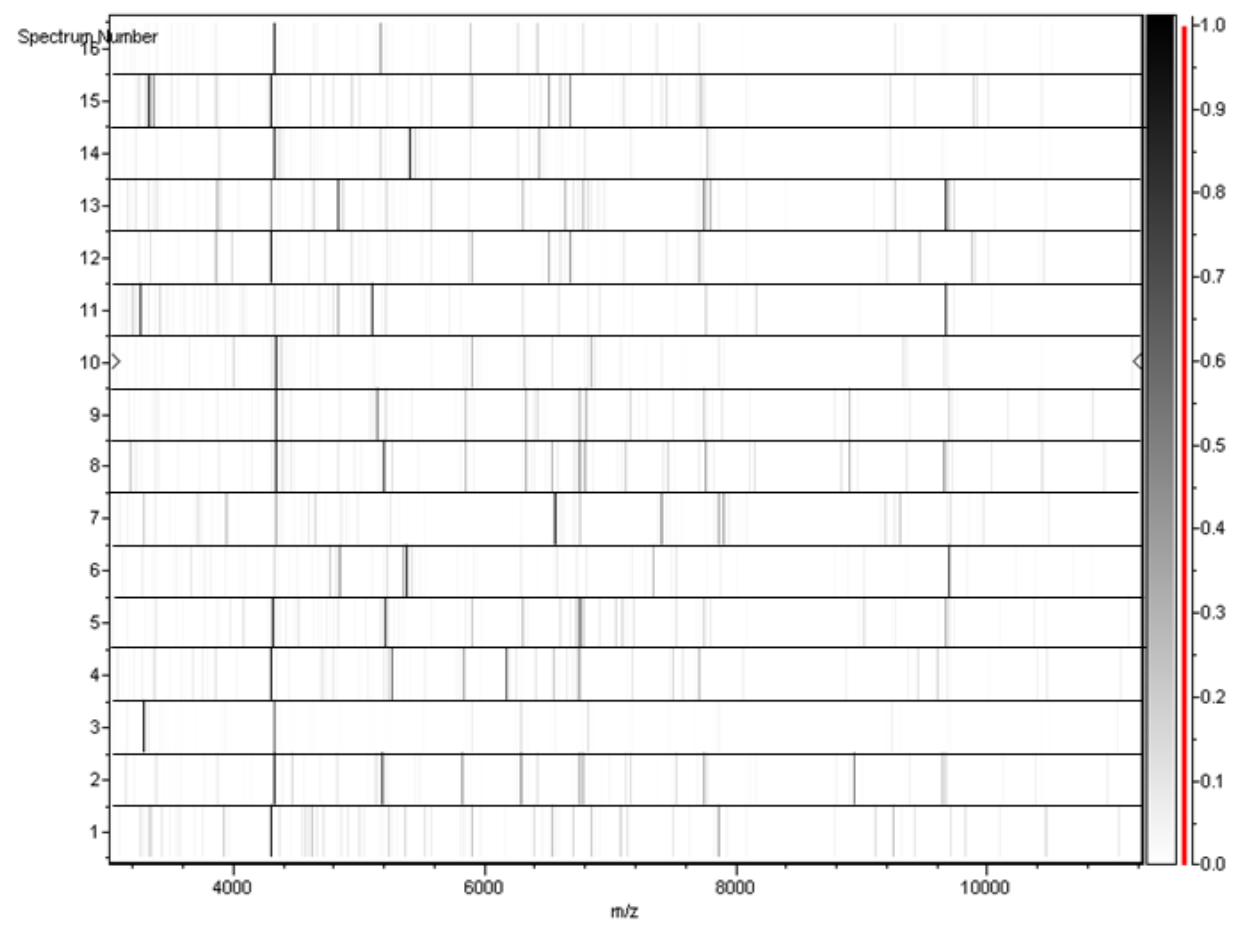

Figure 5. Gel view comparing Bacillus algeriensis $\mathrm{EB} 01^{\top}$ spectra with other members of the Bacillus genus ( $B$. weihenstephanensis, B. vallismortis, $B$. thuringiensis, B. thioparans, B. subtilis subsp. subtilis, $B$. subterraneus, $B$. shackletonii, B. novalis, B. niacini, B. nealsonii, B. jeotgali, B. flexus, B. circulans, B. bataviensis and B. asahii). The Gel View displays the raw spectra of all loaded spectrum files as a pseudo-electrophoretic gel. The $\mathrm{x}$-axis records the $\mathrm{m} / \mathrm{z}$ value. The left $\mathrm{y}$-axis displays the running spectrum number originating from subsequent spectra loading. The peak intensity is expressed by a grey scale scheme code. The grey scale bar on the right y-axis indicates the relation between the shade of grey a peak is displayed with and the peak intensity in arbitrary units. 
Bendjama et al.

\section{Genome sequencing information}

\section{Genome project history}

The organism was selected for sequencing on the basis of its phylogenetic position and 16S rRNA similarity to other members of the genus Bacillus, and is part of a study of Bacillus genus diversity in hypersaline lakes of Algeria. It was the 398 ${ }^{\text {th }}$ ge- nome of a Bacillus species and the first genome of Bacillus algeriensis sp. nov. The EMBL accession number is ERP003483 and consists of 46 contigs. Table 3 shows the project information and its association with MIGS version 2.0 compliance [51].

Table 3. Project information

\begin{tabular}{lll}
\hline MIGS ID & Property & Term \\
\hline MIGS-31 & Finishing quality & High-quality draft \\
MIGS-28 & Libraries used & Nextera XT library \\
MIGS-29 & Sequencing platform & Miseq-Illumina \\
MIGS-31.2 & Sequencing coverage & $34 \times$ \\
MIGS-30 & Assemblers & Velvet \\
MIGS-32 & Gene calling method & Prodigal \\
& EMBL Date of Release & January 10, 2014 \\
& EMBL ID & ERP003483 \\
& & Study of the Bacillus genus diversity in \\
MIGS-13 & Project relevance & hypersaline lakes of northeastern Algeria \\
\hline
\end{tabular}

\section{Growth conditions and DNA isolation}

Bacillus algeriensis sp. nov strain EB01 ${ }^{\mathrm{T}}$, was grown aerobically on $5 \%$ sheep blood enriched Columbia agar at $37^{\circ} \mathrm{C}$. Three Petri dishes were spread and resuspended in a $2 \mathrm{ml}$ sterile Eppendorf tube containing $1 \mathrm{ml}$ of TE buffer with acid-washed glass beads (diameter $\leq 106 \mu \mathrm{m}$, Sigma, Saint-Quentin Fallavier, France). Three cycles of shaking were performed using a FastPrep BIO 101 apparatus (Qbiogene, Strasbourg, France) for $15 \mathrm{sec}$ at level 6.5 (full speed). Then, the supernatant was placed in a new tube along with one hundred $\mu \mathrm{l}$ of $10 \%$ SDS and $50 \mu \mathrm{l}$ of Proteinase K (Qiagen $\mathrm{GmbH}$, Hilden, Germany) and incubated over night at $56^{\circ} \mathrm{C}$. The digested mixture was used to perform DNA extraction using the classical phenol-chloroform method. The quality of the DNA was checked on an agarose gel $(0.8 \%)$ stained with SYBR safe.

\section{Genome sequencing}

Genomic DNA of $B$. algeriensis sp. nov. strain EB01 ${ }^{\mathrm{T}}$ was sequenced on the MiSeq platform (Illumina, Inc, San Diego CA 92121, USA) with a paired end and barcode strategy in order to be mixed with 7 others genomic projects constructed with the Nextera XT library kit (Illumina).

The gDNA was quantified by a Qubit assay with the high sensitivity kit (Life technologies, Carlsbad, CA, USA) to $34.4 \mathrm{ng} / \mu \mathrm{L}$ and dilution was performed to provide $1 \mathrm{ng}$ of each small genome as input. The "tagmentation" step fragmented and tagged the DNA to generate an optimum insert size of $1.6 \mathrm{~kb}$, validated on a high sensitivity labchip Calliper-Perkin Elmer (Caliper Life Sciences, Inc, Massachusetts, USA). Then limited cycle PCR amplification completed the tags adapters and introduced dual-index barcodes. After purification on Ampure beads (Lifetechnolgies, Carlsbad, CA, USA), the libraries were normalized on specific beads according to the Nextera XT protocol (Illumina). Normalized libraries are pooled into a single library for sequencing on the MiSeq. The pooled single strand library was loaded onto the reagent cartridge and then onto the instrument along with the flow cell. Automated cluster generation and paired-end sequencing with dual index reads was performed in a single 39-hour run with a $2 \times 250$ bp read length. Within this pooled run, the index representation was determined to $7.1 \%$. Total information of $2.4 \mathrm{G}$ bases was obtained from a $320 \mathrm{~K} / \mathrm{mm} 2$ density with $94.9 \%(5,757,000$ clusters $)$ of the clusters passing quality control (QC) filters. From the genome sequencing process, the 775,420 produced Illumina reads for $B$. algeriensis $\mathrm{EB} 01^{\mathrm{T}}$ were filtered according to the read qualities and sizes using the fastq-mcf program (Ea-utils: command-line tools for processing biological sequencing data) [52]. 714,540 filtered read sequences were kept for genome assembly. The Velvet assembler was used with different kmer values (from 51 to 95) and the best assembly result with kmer value $(n=91)$ producing 46 contigs with sizes from 872 bp to $409,112 \mathrm{bp}$, was retained for genome annotation. 


\section{Genome annotation}

Open Reading Frames (ORFs) were predicted using Prodigal [53] with default parameters. The predicted bacterial protein sequences were searched against the Clusters of Orthologous Groups (COG) database and the GenBank database [54] using BLASTP. Ribosomal RNAs were found by using RNAmmer 2.1 server $[55,56]$ and BLASTn against the GenBank database, whereas the tRNAScanSE tool [57] was used to find tRNA genes. Transmembrane helices and lipoprotein signal peptides were predicted using phobius web server [58]. ORFans were identified if their BLASTP $E$-value was lower than 1e-03 for alignment length greater than 80 amino acids. If alignment lengths were smaller than 80 amino acids, we used an $E$-value of $1 \mathrm{e}-05$. Artemis [59] was used for data management and DNA Plotter [60] was used for visualization of genomic features. To estimate the mean level of nucleotide sequence similarity at the genome level between $B$. algeriensis sp nov. strain $\mathrm{EB} 01^{\mathrm{T}}$ and seven other Bacillus species, we use the Average Genomic Identity of Orthologous gene Sequences (AGIOS) in-house software. Briefly, this software combines the Proteinortho software [61] for pairwise comparison and detection of orthologous proteins between genomes, then retrieves the corresponding genes and determines the mean percentage of nucleotide sequence identity among orthologous ORFs using the Needleman-Wunsch global alignment algorithm.

\section{Genome properties}

The genome is 5,269,577 bp long with $42.22 \%$ GC content (Figure 6 and Table 4). It is composed of 46 contigs. Of the 5,193 predicted genes, 5,098 were protein-coding genes, and 95 were RNAs $(10$ genes encode 5S rRNA, 1 gene encodes 16S rRNA, 1 gene encodes 23S rRNA, 83 genes are tRNA genes). A total of 3,217 genes (63.1\%) were assigned a putative function (by cogs or by NR blast). 457 genes were identified as ORFans (8.96\%). The remaining genes were annotated as hypothetical proteins (1,097 genes, $21.52 \%)$. The distribution of genes into COGs functional categories is presented in Table 5 . The properties and statistics of the genome are summarized in Tables 4 and 5.

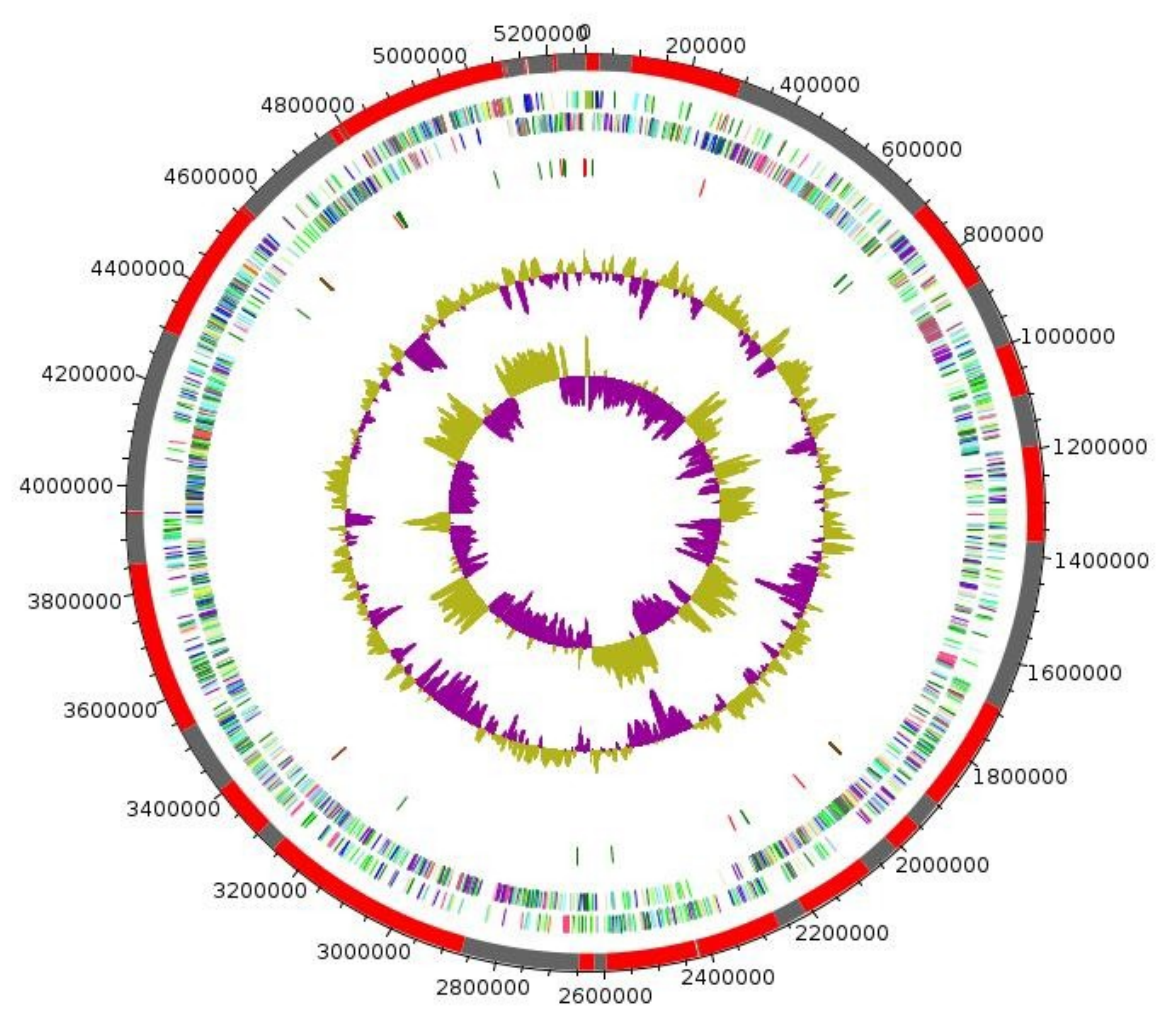

Figure 6. Graphical circular map of the chromosome. From outside to the center: Red and gray bars representing contigs, genes on the forward strand colored by COG categories (only genes assigned to COG), genes on the reverse strand colored by COG categories (only genes assigned to COG), RNA genes (tRNAs green, rRNAs red), GC content. The inner-most circle shows the GC skew, purple and olive indicating negative and positive values, respectively. 
Bendjama et al.

Table 4. Nucleotide content and gene count levels of the genome

\begin{tabular}{|c|c|c|}
\hline Attribute & Value & $\%$ of total ${ }^{\mathrm{a}}$ \\
\hline Genome size (bp) & $5,269,577$ & 100 \\
\hline Coding region (bp) & $4,342,253$ & 82.4 \\
\hline $\mathrm{G}+\mathrm{C}$ content $(\mathrm{bp})$ & $2,224,760$ & 42.22 \\
\hline Total genes & 5,193 & 100 \\
\hline RNA genes & 95 & 1.82 \\
\hline Protein-coding genes & 5,098 & 98.17 \\
\hline Genes with function prediction & 3,217 & 63.1 \\
\hline Genes assigned to COGs & 3,041 & 59.65 \\
\hline Genes with peptide signals & 653 & 12.8 \\
\hline Genes with transmembrane helices & 1,297 & 25.44 \\
\hline
\end{tabular}

a The total is based on either the size of the genome in base pairs or the total number of protein coding genes in the annotated genome

Table 5. Number of genes associated with the 25 general COG functional categories

\begin{tabular}{|c|c|c|c|}
\hline Code & Value & $\%$ age $^{\mathrm{a}}$ & Description \\
\hline$J$ & 176 & 3.45 & Translation, ribosomal structure and biogenesis \\
\hline A & 0 & 0 & RNA processing and modification \\
\hline K & 281 & 5.51 & Transcription \\
\hline $\mathrm{L}$ & 165 & 3.23 & Replication, recombination and repair \\
\hline B & 1 & 0.01 & Chromatin structure and dynamics \\
\hline $\mathrm{D}$ & 33 & 0.64 & Cell cycle control, mitosis and meiosis \\
\hline $\mathrm{Y}$ & 0 & 0 & Nuclear structure \\
\hline $\mathrm{V}$ & 63 & 1.23 & Defense mechanisms \\
\hline $\mathrm{T}$ & 144 & 2.82 & Signal transduction mechanisms \\
\hline M & 156 & 3.06 & Cell wall/membrane biogenesis \\
\hline $\mathrm{N}$ & 48 & 0.94 & Cell motility \\
\hline Z & 0 & 0 & Cytoskeleton \\
\hline W & 0 & 0 & Extracellular structures \\
\hline$U$ & 50 & 0.98 & Intracellular trafficking and secretion \\
\hline $\mathrm{O}$ & 110 & 2.15 & Posttranslational modification, protein turnover, chaperones \\
\hline $\mathrm{C}$ & 206 & 4.04 & Energy production and conversion \\
\hline G & 277 & 5.43 & Carbohydrate transport and metabolism \\
\hline $\mathrm{E}$ & 370 & 7.25 & Amino acid transport and metabolism \\
\hline $\mathrm{F}$ & 82 & 1.60 & Nucleotide transport and metabolism \\
\hline $\mathrm{H}$ & 109 & 2.13 & Coenzyme transport and metabolism \\
\hline I & 142 & 2.78 & Lipid transport and metabolism \\
\hline $\mathrm{P}$ & 213 & 4.17 & Inorganic ion transport and metabolism \\
\hline Q & 86 & 1.68 & Secondary metabolites biosynthesis, transport and catabolism \\
\hline $\mathrm{R}$ & 521 & 10.21 & General function prediction only \\
\hline S & 327 & 6.41 & Function unknown \\
\hline- & 2,057 & 40.34 & Not in COGs \\
\hline
\end{tabular}

a The total is based on the total number of protein coding genes in the annotated genome 


\section{Comparison with other species Bacil- lus genomes}

Here, we compared the genome of $B$. algeriensis strain EB01 ${ }^{\mathrm{T}}$ with those of $B$. kribbensis strain DSM 17871, B. nealsonii strain AAU1, B. bataviensis strain LMG 21833, B. subtilis subsp. subtilis strain $168, B$. vallismortis strain DV1-F-3, B. thuringiensis strain BMB171 and $B$. weihenstephanensis strain KBAB4 (Table 6). The draft genome of $B$. algeriensis $(5.26 \mathrm{Mb})$ is larger in size than those of B. kribbensis, B. nealsonii, B. subtilis subsp. subtilis and $B$. vallismortis $(5.05,4.98,4.22$ and $3.88 \mathrm{Mb}$, respectively) but smaller than those of, $B$. bataviensis, $B$. thuringiensis and $B$. weihenstephanensis (5.37, 5.64 and $5.87 \mathrm{Mb}$, respectively). $B$. algeriensis has a lower $\mathrm{G}+\mathrm{C}$ content than B. kribbensis, B. subtilis subsp. subtilis and $B$. vallismortis ( $42.22 \%$ vs $43 \%, 43.5 \%$ and $43.8 \%$, respectively) but higher than $B$. nealsonii, $B$. bataviensis, $B$. thuringiensis and $B$. weihenstephanensis $(42.22 \%$ vs $35.1 \%, 39.6 \%$,
$35.2 \%$ and $35.5 \%$, respectively). B. algeriensis has more predicted protein coding genes $(5,098)$ than B. kribbensis, B. nealsonii, B. subtilis subsp. subtilis and $B$. vallismortis $(4,918,4,789,4,175$ and 4,097, respectively) but fewer protein coding genes than $B$. bataviensis, $B$. thuringiensis and $B$. weihenstephanensis $(5,207,5,352$ and 5,653, respectively). In addition, $B$. algeriensis shared $1,804,1,778,2,017,1,768,1,985,1,541,1,863$ orthologous genes with $B$. thuringiensis, $B$. nealsonii, $B$. bataviensis, $B$. subtilis subsp. subtilis, $B$. kribbensis, B. vallismortis, $B$. weihenstephanensis respectively.

The average nucleotide sequence identity of orthologous genes ranges from 64.54 to $91.06 \%$ among the 8 Bacillus species, and from 64.77 to $69.33 \%$ between Bacillus algeriensis and the other compared genomes (Table 7), thus confirming its new species status.

Table 6. Genomic comparison of $B$. algeriensis sp. nov. strain $\mathrm{EB} 01^{\top}$ with seven other Bacillus species ${ }^{\dagger}$.

\begin{tabular}{lllll}
\hline Species & Strain & $\begin{array}{l}\text { Genome accession } \\
\text { number }\end{array}$ & $\begin{array}{l}\text { Genome size } \\
\text { (Mb) }\end{array}$ & $\begin{array}{l}\text { G+C } \\
\text { content }\end{array}$ \\
Bacillus algeriensis & EB01 ${ }^{\top}$ & ERP003483 & 5.26 & 42.22 \\
Bacillus kribbensis & DSM 17871 & AUMQ00000000.1 & 5.05 & 43 \\
Bacillus nealsonii & AAU1 & ASRU00000000.1 & 4.98 & 35.1 \\
Bacillus bataviensis & LMG 21833 & AJLS00000000.1 & 5.37 & 43.5 \\
Bacillus subtilis subsp. subtilis & 168 & NC_000964.3 & 4.22 & 43.8 \\
Bacillus vallismortis & & & 3.88 & 35.2 \\
Bacillus thuringiensis & DV1-F-3 & AFSH00000000.1 & 35.5 \\
\hline Bacillus weihenstephanensis & KBAB4 & NC_014171.1 & 5.64 & \\
\hline
\end{tabular}

${ }^{+}$species and strain names, genome accession numbers, sizes and $\mathrm{G}+\mathrm{C}$ contents. 


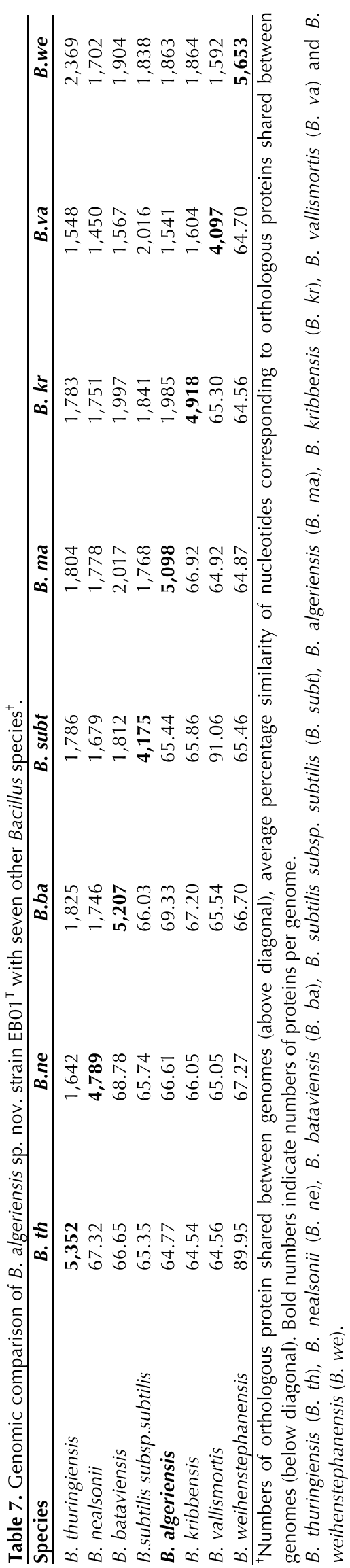




\section{Conclusion}

On the basis of phenotypic (Table 2), phylogenetic and genomic analyses (taxonogenomics) (Table 6), we formally propose the creation of Bacillus algeriensis sp. nov. that contains the strain EB01T. This strain has been found in hypersaline lacustrine sediment sample collected from Algeria.

\section{Description of Bacillus algeriensis sp. nov.}

Bacillus algeriensis (al.ge.ri.en'sis. NL. masc.adj. algeriensis, of or pertaining to Algeria). Strain EB01 ${ }^{\mathrm{T}}$ is a facultative anaerobic Gram-positive, endospore-forming, motile and rod shaped bacterium with rounded ends. Growth is achieved aerobically between 30 and $55^{\circ} \mathrm{C}$ (optimum $37^{\circ} \mathrm{C}$ ), between $0 \%$ and $2.5 \% \mathrm{NaCl}$ concentration and $\mathrm{pH}$ in the range of 6.5-9 (optimum at pH 7). Growth is also observed in microaerophilic atmosphere, however, weak growth was observed under anaerobic conditions. After $24 \mathrm{~h}$ growth on $5 \%$ sheep blood-enriched Columbia agar (BioMerieux) at $37^{\circ} \mathrm{C}$, bacterial colonies were smooth, light yellow with $2 \mathrm{~mm}$ in diameter. Cells have a length ranging from $2.4 \mu \mathrm{m}$ to $4.9 \mu \mathrm{m}$ (mean $3.6 \mu \mathrm{m}$ ) and a diameter ranging from $0.7 \mu \mathrm{m}$ to $1.1 \mu \mathrm{m}$ (mean $0.8 \mu \mathrm{m}$ ).

Catalase positive but oxidase negative. Using the commercially available API $50 \mathrm{CH}$ system (BioMerieux) according to the manufacturer's instructions, a weak positive reaction was observed for D-ribose, D-glucose, D-fructose, methyl $\alpha$-Dglucopyranoside, $\mathrm{N}$-acetylglucosamine, $\mathrm{D}$-maltose,

\section{References}

1. Cohn F. Untersuchungen über Bakterien. Beitr Biol Pflanz 1872; 1:127-224.

2. Parte AC. LPSN-list of prokaryotic names with standing in nomenclature. Nucleic Acids Res 2013; 42:613-616. PubMed http://dx.doi.org/10.1093/nar/gkt1111

3. Nicholson WL. Roles of Bacillus endospores in the environment. Cell Mol Life Sci 2002; 59:410416. PubMed http://dx.doi.org/10.1007/s00018$\underline{002-8433-7}$

4. Moshafi MH, Forootanfar $\mathrm{H}$, Ameri A, Shakibaie M, Noudeh G, Razavi M. Antimicrobial activity of Bacillus sp. strain FAS1 isolated from soil. Pak J Pharm Sci 2011; 24:269-275. PubMed

5. Bumpus SB, Evans BS, Thomas PM, Ntai I, Kelleher NL. A proteomics approach to discovering natural products and their biosynthetic pathways.
D-lactose, D-melibiose, D-saccharose, D-trehalose, D-tagatose, and hydrolysis of starch. Other tests were negative. Using the API ZYM system (BioMerieux), positive reactions were observed for alkaline phosphatase, esterase (C4), esterase lipase (C8), leucine arylamidase, $\alpha$ chymotrypsin, $\beta$-glucuronidase, $\alpha$-glucosidase, $\mathrm{N}$-acetyl-glucosaminidase and a weak positive reaction was observed for acid phosphatase. The nitrate reduction and $\beta$-galactosidase reaction was also positive, but urease and indole production were negative. $B$. algeriensis was susceptible to amoxicillin, nitrofurantoin, erythromycin, doxycycline, rifampin, vancomycin, gentamycin, imipenem, trimethoprim-sulfamethoxazole, ciprofloxacin, ceftriaxone and amoxicillin/clavulanic acid, but resistant to nalidixic acid.

The $\mathrm{G}+\mathrm{C}$ content of the genome is 42.22 . The $16 \mathrm{~S}$ rRNA and genome sequences are deposited in GenBank under accession numbers HG315679 and EMBL database under accession number ERP003483, respectively. The type strain EB01 ${ }^{\mathrm{T}}$ $(=$ CSUR P857 = DSM 27334) was isolated from sediment sample of the hypersaline lake Ezzemoul sabkha of Oum-El-Bouaghi region in northeastern Algeria.

\section{Acknowledgements}

The authors thank Linda Hadjadj for technical assistance and Xegen company for automating the genome annotation process.

Nat Biotechnol 2009; 27:951-960. PubMed http://dx.doi.org/10.1038/nbt.1565

6. Jernigan JA, Stephens DS, Ashford DA, Omenaca C, Topiel MS, Galbraith M, Tapper M, Fisk TL, Zaki S, Popovic T, et al. Bioterrorism-related inhalational anthrax: the first 10 cases reported in the United States. Emerg Infect Dis 2001; 7:933-944. PubMed http://dx.doi.org/10.3201/eid0706.010604

7. Bottone EJ. Bacillus cereus, a volatile human pathogen. Clin Microbiol Rev 2010; 23:382-398. PubMed http://dx.doi.org/10.1128/CMR.00073-09

8. Mandell GL, Bennett JE, Dolin R. Principles and Practice of Infectious Diseases. Elsevier 2010, 4320p.

9. Stackebrandt E, Frederiksen W, Garrity GM, Grimont PA, Kämpfer P, Maiden MC, Nesme X, Rosselló-Mora R, Swings J, Trüper HG, et al. Re- 
Bendjama et al.

port of the ad hoc committee for the re-evaluation of the species definition in bacteriology. Int J Syst Evol Microbiol 2002; 52:1043-1047. PubMed http://dx.doi.org/10.1099/ijs.0.02360-0

10. Tindall BJ, Rossello-Mora R, Busse HJ, Ludwig W, Kampfer P. Notes on the characterization of prokaryote strains for taxonomic purposes. Int I Syst Evol Microbiol 2010; 60:249-266. PubMed http://dx.doi.org/10.1099/ijs.0.016949-0

11. Stackebrandt E, Ebers J. Taxonomic parameters revisited: tarnished gold standards. Microbial Today 2006; 33:152-155.

12. Rossello-Mora R. DNA-DNA Reassociation Methods Applied to Microbial Taxonomy and Their Critical Evaluation. In: Stackebrandt E (ed), Molecular Identification, Systematics, and population Structure of Prokaryotes. Springer, Berlin 2006. p. 23-50.

13. Welker M, Moore ER. Applications of whole-cell matrix-assisted laser-desorption/ionization timeof-flight mass spectrometry in systematic microbiology. Syst Appl Microbiol 2011; 34:2-11.

PubMed http://dx.doi.org/10.1016/j.syapm.2010.11.013

14. Ramasamy D, Mishra AK, Lagier JC, Padhmanabhan R, Rossi M,Sentausa E, Raoult D, Fournier PE. A polyphasic strategy incorporating genomic data for the taxonomic description of novel bacterial species. Int / Syst Evol Microbiol 2014; 64:384-391.

15. Ramasamy D, Lagier JC, Gorlas A, Raoult D, Fournier PE. Non contiguous-finished genome sequence and description of Bacillus

massiliosenegalensis sp. nov. Stand Genomic Sci 2013; 8:264-278. PubMed http://dx.doi.org/10.4056/sigs.3496989

16. Keita MB, Diene SM, Robert C, Raoult D, Fournier PE, Bittar F. Non-contiguous finished genome sequence and description of Bacillus massiliogorillae sp. nov. Stand Genomic Sci 2013; 9:93-105. PubMed http://dx.doi.org/10.4056/sigs.4388124

17. Mishra AK, Pfleiderer A, Lagier JC, Robert C, Raoult D, Fournier PE. Non-contiguous finished genome sequence and description of Bacillus massilioanorexius sp. nov. Stand Genomic Sci 2013; 8:465-479. PubMed http://dx.doi.org/10.4056/sigs.4087826

18. Kokcha S, Mishra AK, Lagier JC, Million M, Leroy Q, Raoult D, Fournier PE. Non contiguousfinished genome sequence and description of $\mathrm{Ba}$ cillus timonensis sp. nov. Stand Genomic Sci
2012; 6:346-355. PubMed

http://dx.doi.org/10.4056/sigs.2776064

19. Mishra AK, Lagier JC, Rivet O, Raoult D, Fournier $P E$. Non-contiguous finished genome sequence and description of Paenibacillus senegalensis sp. nov. Stand Genomic Sci 2012; 7:70-81. PubMed http://dx.doi.org/10.4056/sigs.3056450

20. Mishra AK, Lagier JC, Robert C, Raoult D, Fournier PE. Genome sequence and description of Timonella senegalensis gen. nov., sp. nov., a new member of the suborder Micrococcinae. Stand Genomic Sci 2013; 8:318-335. PubMed http://dx.doi.org/10.4056/sigs.3476977

21. Ramasamy D, Lagier JC, Nguyen TT, Raoult D, Fournier PE. Non contiguous-finished genome sequence and description of of Dielma fastidiosa gen. nov., sp. nov., a new member of the Family Erysipelotrichaceae. Stand Genomic Sci 2013; 8:336-351. PubMed http://dx.doi.org/10.4056/sigs.3567059

22. Mishra AK, Hugon $P$, Lagier JC, Nguyen TT, Couderc C, Raoult D, Fournier PE. Non contiguous-finished genome sequence and description of Enorma massiliensis gen. nov., sp. nov., a new member of the Family Coriobacteriaceae. Stand Genomic Sci 2013; 8:290-305. PubMed http://dx.doi.org/10.4056/sigs.3426906

23. Hugon $P$, Mishra AK, Lagier JC, Nguyen TT, Couderc C, Raoult D, Fournier PE. Non contiguous-finished genome sequence and description of Brevibacillus massiliensis sp. nov. Stand Genomic Sci 2013; 8:1-14. PubMed http://dx.doi.org/10.4056/sigs.3466975

24. Lagier JC, El Karkouri K, Mishra AK, Robert C, Raoult D, Fournier PE. Non-contiguous finished genome sequence and description of Enterobacter massiliensis sp. nov. Stand Genomic Sci 2013; 7:399-412. PubMed http://dx.doi.org/10.4056/sigs.3396830

25. Mishra AK, Lagier JC, Nguyen TT, Raoult D, Fournier PE. Non-contiguous finished genome sequence and description of Peptoniphilus senegalensis sp. nov. Stand Genomic Sci 2013; 7:370-381. PubMed http://dx.doi.org/10.4056/sigs.3366764

26. Roux V, ElKarkouri K, Lagier JC, Robert C, Raoult $D$. Non-contiguous finished genome sequence and description of Kurthia massiliensis sp. nov. Stand Genomic Sci 2012; 7:221-232. PubMed http://dx.doi.org/10.4056/sigs.3206554

27. Woese CR, Kandler O, Wheelis ML. Towards a natural system of organisms: proposal for the do- 
mains Archaea, Bacteria, and Eucarya. Proc Natl Acad Sci USA 1990; 87:4576-4579. PubMed http://dx.doi.org/10.1073/pnas.87.12.4576

28. Gibbons NE, Murray RGE. Proposals concerning the higher taxa of bacteria. Int J Syst Bacteriol 1978; 28:1-6. http://dx.doi.org/10.1099/00207713-28-1-1

29. Murray RGE. The Higher Taxa, or, a Place for Everything...? In: Holt JG (ed). Bergey's Manual of Systematic Bacteriology, First Edition, Volume 1, The Williams and Wilkins Co, Baltimore 1984; p. 31-34.

30. Garrity GM, Holt JG. The Road Map to the Manual. In: Garrity GM, Boone DR, Castenholz RW (eds), Bergey's Manual of Systematic Bacteriology, Second Edition, Volume 1, Springer, New York, 2001, p. 119-169.

31. Ludwig W, Schleifer KH, Whitman WB. Class I. Bacilli class nov. In: De Vos P, Garrity GM, Jones D, N.R. Krieg W. Ludwig W, Rainey EA, Schleifer KH, Withman WB. Bergey's Manual of Systematic Bacteriology, second edition, vol 3 (The Firmicutes), Springer, Dordrecht, Heidelberg, London, New York 2009, pp.19-20.

32. List of new names and new combinations previously effectively, but not validly, published. List no. 132. Int I Syst Evol Microbiol 2010; 60:469472. http://dx.doi.org/10.1099/ijs.0.022855-0

33. Skerman VBD, McGowan V, Sneath PHA, eds. Approved Lists of Bacterial Names. Int / Syst Bacteriol 1980; 30:225-420. http://dx.doi.org/10.1099/00207713-30-1-225

34. Prévot AR. In: Hauduroy P, Ehringer G, Guillot G, Magrou J, Prévot AR, Rosset. Urbain A (eds) Dictionnaire des Bactéries Pathogènes, 2nd ed., Masson, Paris, 1953, pp. 1-692.

35. Fischer A. Untersuchungen über bakterien. Jahrbücher für Wissenschaftliche Botanik 1985; 27:1-163.

36. Gibson T, Gordon RE. Genus I. Bacillus Cohn 1872; 174; Nom. gen. cons. Nomencl. Comm. Intern. Soc. Microbiol. 1937, 28; Opin. A. Jud. Comm. 1955, 39. In: Buchanan RE, Gibbons NE (eds), Bergey's Manual of Determinative Bacteriology, Eighth Edition, The Williams and Wilkins Co., Baltimore, 1974, p. 529-550.

37. Ashburner M, Ball CA, Blake JA, Botstein D, Butler H, Cherry JM, Davis AP, Dolinski K, Dwight SS, Eppig J T et al. Gene ontology: tool for the unification of biology. The Gene Ontology Consortium. Nat Genet 2000; 25:25-29. PubMed http://dx.doi.org/10.1038/75556
38. Saitou N, Nei M. The neighbor-joining method: a new method for reconstructing phylogenetic trees. Mol Biol Evol 1987; 4:406-425. PubMed

39. Tamura K, Peterson D, Peterson N, Stecher G, Nei M, Kumar S. MEGA5: molecular evolutionary genetics analysis using maximum likelihood, evolutionary distance, and maximum parsimony methods. Mol Biol Evol 2011; 28:2731-2739. PubMed http://dx.doi.org/10.1093/molbev/msr121

40. Kanso S, Greene AC, Patel BKC. Bacillus subterraneus sp. nov., an iron- and manganesereducing bacterium from a deep subsurface Australian thermal aquifer. Int I Syst Evol Microbiol 2002; 52:869-874. PubMed http://dx.doi.org/10.1099/ijs.0.01842-0

41. Tiago I, Pires C, Mendes V, Morais PV, da Costa MS, Verissimo A. Bacillus foraminis sp. nov., isolated from a non-saline alkaline groundwater. Int J Syst Evol Microbiol 2006; 56:2571-2574. PubMed http://dx.doi.org/10.1099/ijs.0.64281-0

42. Yoon JH, Kang SS, Lee KC, Kho YH, Choi SH, Kang KH, Park YH. Bacillus jeotgali sp. nov., isolated from jeotgal, Korean traditional fermented seafood. Int J Syst Evol Microbiol 2001; 51:10871092. PubMed http://dx.doi.org/10.1099/00207713-51-3-1087

43. Euzeby J. Validation List no. 117. List of new names and new combinations previously effectively, but not validly, published. Int I Syst Evol Microbiol 2007; 57:1933-1934. PubMed http://dx.doi.org/10.1099/ijs.0.65495-0

44. Perez-Ibarra BM, Flores ME, Garcia-Varela M. Isolation and characterization of Bacillus thioparus sp. nov., chemolithoautotrophic, thiosulfate-oxidizing bacterium. FEMS Microbiol Lett 2007; 271:289-296. PubMed http://dx.doi.org/10.1111/j.15746968.2007.00729.x

45. Ahmed I, Yokota A, Fujiwara T. A novel highly boron tolerant bacterium, Bacillus boroniphilus sp. nov., isolated from soil, that requires boron for its growth. Extremophiles 2007; 11:217-224. PubMed http://dx.doi.org/10.1007/s00792-006$\underline{0027-0}$

46. Heyrman J, Vanparys B, Logan NA, Balcaen A, Rodrıguez-Dıaz M, Felske A, De Vos P. Bacillus novalis sp. nov., Bacillus vireti sp. nov., Bacillus soli sp. nov., Bacillus bataviensis sp. nov. and $\mathrm{Ba}$ cillus drentensis sp. nov., from the Drentse A grasslands. Int J Syst Evol Microbiol 2004; 54:47- 
57. PubMed

http://dx.doi.org/10.1099/ijs.0.02723-0

47. Venkateswaran K, Kempf M, Chen F, Satomi M, Nicholson W, Kern R. Bacillus nealsonii sp. nov., isolated from a spacecraft-assembly facility, whose spores are gamma-radiation resistant. Int J Syst Evol Microbiol 2003; 53:165-172. PubMed http://dx.doi.org/10.1099/ijs.0.02311-0

48. Lim JM, Jeon CO, Lee JR, Park DJ, Kim CJ. Bacillus kribbensis sp. nov., isolated from a soil sample in Jeju, Korea. Int J Syst Evol Microbiol 2007; 57:2912-2916. PubMed http://dx.doi.org/10.1099/ijs.0.65227-0

49. Seng $P$, Rolain JM, Fournier PE, La Scola B, Drancourt M, Raoult D. MALDI-TOF-mass spectrometry applications in clinical microbiology. Future Microbiol 2010; 5:1733-1754. PubMed http://dx.doi.org/10.2217/fmb.10.127

50. Seng P, Drancourt M, Gouriet F, La Scola B, Fournier PE, Rolain JM, Raoult D. Ongoing revolution in bacteriology: routine identification of bacteria by matrix-assisted laser desorption ionization time-of-flight mass spectrometry. Clin Infect Dis 2009; 49:543-551. PubMed http://dx.doi.org/10.1086/600885

51. Field D, Garrity G, Gray T, Morrison N, Selengut J, Sterk P, Tatusova T, Thomson N, Allen MJ, Angiuoli SV, et al. The minimum information about a genome sequence (MIGS) specification. Nat Biotechnol 2008; 26:541-547. PubMed http://dx.doi.org/10.1038/nbt1360

52. fastq-mcf program. http://code.google.com/p/ea$\underline{\text { utils }}$

53. Prodigal. http://prodigal.ornl.gov
54. GenBank database. http://www.ncbi.nlm.nih.gov/genbank

55. RNAmmer 1.2 Server. http://www.cbs.dtu.dk/services/RNAmmer/

56. Lagesen K, Hallin P, Rodland EA, Staerfeldt HH, Rognes T, Ussery DW. RNAmmer: consistent and rapid annotation of ribosomal RNA genes. Nucleic Acids Res 2007; 35:3100-3108. PubMed http://dx.doi.org/10.1093/nar/gkm160

57. Lowe TM, Eddy SR. tRNAscan-SE: a program for improved detection of transfer RNA genes in genomic sequence. Nucleic Acids Res 1997;

25:955-964. PubMed http://dx.doi.org/10.1093/nar/25.5.0955

58. Kall L, Krogh A, Sonnhammer EL. Advantages of combined transmembrane topology and signal peptide prediction--the Phobius web server. $\mathrm{Nu}$ cleic Acids Res 2007; 35:W429-W432. PubMed http://dx.doi.org/10.1093/nar/gkm256

59. Rutherford K, Parkhill J, Crook J, Horsnell T, Rice P, Rajandream MA, Barrell B. Artemis: sequence visualization and annotation. Bioinformatics 2000; 16:944-945. PubMed http://dx.doi.org/10.1093/bioinformatics/16.10.944

60. Carver T, Thomson N, Bleasby A, Berriman M, Parkhill J. DNAPlotter: circular and linear interactive genome visualization. Bioinformatics 2009; 25:119-120. PubMed http://dx.doi.org/10.1093/bioinformatics/btn578

61. Lechner M, Findeiss S, Steiner L, Marz M, Stadler PF, Prohaska SJ. Proteinortho: detection of (CO)orthologs in large-scale analysis. BMC Bioinformatics $2011 ; 12: 124-133$. PubMed http://dx.doi.org/10.1186/1471-2105-12-124 